\title{
POSSIBLE PROTECTIVE EFFECT OF OLIVE LEAVES EXTRACT ON PARACETAMOL INDUCED HEPATOTOXICITY IN MALE ALBINO RATS
}

\author{
POSSÍVEL EFEITO PROTETOR DO EXTRATO DE FOLHAS DE OLIVEIRA NA \\ HEPATOTOXICIDADE INDUZIDA POR PARACETAMOL EM RATOS ALBINOS \\ MACHOS
}

\author{
Mervat EI Sayed TAHA ${ }^{1}$; Amaal Mohamed KAMAL ${ }^{1}$; Dalia Ramzy IBRAHIM1 \\ 1. Biological Applications Department, Nuclear Research Center, Atomic Energy Authority, Cairo, Egypt \\ Mervattaha12@gmail.com
}

\begin{abstract}
Paracetamol (PCM) overdose can cause hepatotoxicity with oxidative stress; the present study was carried out to establish the possible protective effect of olive leaves extract (OLE) on toxicity induced by paracetamol in adult male rats. Twenty four adult male rats were divided into four equal groups; control, olive leaves extract group, paracetamol group and olive leaves extract plus paracetamol group. Some biochemical parameters and liver histopathology were evaluated. PCM treatment significantly increased serum aspartate aminotransferase (AST), alanine aminotransferase (ALT), total bilirubin, gamma-glutamyltransferase (GGT), lactate dehydrogenase (LDH), urea, creatinine and alpha-fetoprotein. Paracetamol was found to significantly increase malonaldehyde (MDA) and decrease glutathione reductase (GR) activity in tissue and significantly decrease total antioxidant capacity (TAC) and superoxide dismutase (SOD) in serum. Administration of OLE caused a significant decrease serum AST, ALT enzyme, total bilirubin, GGT, LDH, creatinine, urea, alpha-fetoprotein. Also, amelioration of oxidant - antioxidant status with olive leaves extract was observed in addition to a significant decrease in MDA and a significant increase in TAC in liver tissue with a significant increase in glutathione reductase (GR) and SOD in serum compared to paracetamol treated group The chemical pathological changes were in step with histopathological observation suggesting marked hepatoprotective result of olive leaves extract. It could be concluded that olive leaves extract (OLE) treatment may be effective in decreasing hepatic injury and oxidative stress induced by paracetamol overdose in male albino rats
\end{abstract}

KEYWORDS: Paracetamol. Olive leaves extract. Liver enzymes. Oxidan - antioxidant status.

\section{INTRODUCTION}

Liver is one of the most important organs in the body that functions as a center for metabolism of nutrients such as carbohydrates, proteins, and lipids. It is also involved in the metabolism and excretion of waste metabolites and drugs, thereby providing protection against foreign substances by detoxifying and eliminating them (MOHAMED-SALEEM et al., 2010). Hepatotoxicity occurs due to drugs steroids, vaccines, antiviral and other medications (SEHRAWAT et al., 2006; RUSSMANN; KULLAK-UBLICK; GRATTAGLINO, 2009).

Paracetamol is widely used as antipyretic. It is a safe drug when given in therapeutic doses, but its overdose can lead to acute liver damage in humans. The hepatotoxicity of paracetamol has been attributed to the formation of toxic metabolites when a part of paracetamol is activated by hepatic cytochrome P-450 (DAS et al., 2010) to a highly reactive metabolite $\mathrm{N}$-acetyl-P-benzoquinoneimine (NAPQI), which in turn, binds covalently to tissue macromolecules, thereby causing severe hepatic damage.(KIM et al., 2009; KUMAR; RAMESH; MOHAN, 2014). Nephrotoxicity is less common than hepatotoxicity in PCM overdose, renal tubular damage and acute renal failure can occur even in the absence of liver injury (CHINNAPPAN et al.,2019)

Herbal drugs play a role in the management of various liver disorders most of which speed up the natural healing processes of the liver (SUBRAMONIAM et al., 1988). The olive tree (Oleaeuropaea L.) family: Oleaceae is commonly used as a part of traditional herbal medicine to treat disease in the Mediterranean area (HAKEMI et al., 2019). Phytoconstituents such as flavonoids, glycosides, triterpenoids, carbohydrates, steroids, polyphenols present in OLE revealed various therapeutic potentials against many diseases including diabetes, wounds, fever, gout, atherosclerosis, and hypertension (WANG et al., 2008; AL-BASHER 2018). 
Possible protective...

TAHA, M. E. S.; KAMAL, A. M.; IBRAHIM, D. R.
The purpose of this work was to clarify the hepatoprotective and antioxidant role of olive leaves extract on paracetamol overdose effect in male rats.

\section{MATERIAL AND METHODS}

\section{Drugs}

Panadol (paracetamol) (500mg) was purchased from Alexandria Company for Pharmaceuticals and Chemicals Industries under License: GlaxoSmithkline Consumer Healthcare Ltd. Ireland

\section{Collection and preparation of olive leaves extraction}

Olive leaves were collected from a local field cultivated by Oleaeuropaea at Nuclear Research Center, Egyptian Atomic Energy Authority, Inshas, Egypt

\section{Extraction procedure}

Extraction process was performed according to Sahin and Samli (2013). One thousand grams of fresh Leaves were washed by running tap water then rinsed by distilled water after drying, leaves were crushed to fine powder, they were soaked in water: ethanol $(1: 1, \mathrm{v}: \mathrm{v})$ for 48 hours, then filtered through Whatman No. 1 filter paper under reduced pressure. The filtrate was extracted by an equal volume of methylene chloride three times. The methylene chloride layer was separated by a separating funnel. The collected methylene chloride layers were filtered over anhydrous sodium sulfate and then evaporated under vacuum until dryness using rotary evaporator (IKA, RV10, Germany). The dried crude extract (approximately $18 \mathrm{gm}$ ) was dissolved in water to the desired concentrations and stored at $7^{\circ} \mathrm{C}$.

\section{Preliminary phytochemical analysis}

Gas chromatography- mass spectrometry (GC / MS) analysis of olive leaves extract was performed and revealed the presence of many bioactive compounds (Table 1).

Table 1. Chemical analysis of olive leaves extract

\begin{tabular}{cccc}
\hline $\boldsymbol{N O}$ & $\boldsymbol{R} \boldsymbol{T}$ & Name & Area Sum\% \\
\hline 1 & 10.4 & ó-Santonin & 3.79 \\
2 & 11.49 & Heptadecanoic acid & 2.8 \\
3 & 12.28 & -epi-shyobunol & 2.45 \\
4 & 12.63 & 1,4-Methanoazulen-7-ol,decahydro-1,5,5,8a- & 2.47 \\
& & tetramethyl--,[1s-1ó,3AB,4ó,7B,8aB] & \\
5 & 12.87 & Neophytadiene & 1.66 \\
6 & 13.06 & Phytol,acetate & 0.54 \\
7 & 13.227 & Phytol & 0.95 \\
8 & 13.46 & Nobiletin & 1.2 \\
9 & 13.72 & Stearic acid(Octadecanoic acid) & 13.14 \\
10 & 14.48 & Rhodopin & 2.84 \\
11 & 14.78 & Arachic acid & 15.22 \\
12 & 14.92 & Stigmasterol & 4.16 \\
13 & 15.56 & B-Sitosterol & 4.09 \\
14 & 16.44 & Isovitexin & 4.69 \\
15 & 16.8 & Cis-Vaccenic acid 11E-Octadec-11-enoic acid & 5.07 \\
16 & 17.8 & -Th-3rocotrienol & 5.5 \\
17 & 19.07 & Desmosterol & 2.12 \\
18 & 19.45 & Phytanic acid & 2.02 \\
19 & 20.6 & Mangiferin & 0.84 \\
20 & 21.71 & Myristoleic acid & 4.08 \\
21 & 21.86 & Astilbin & 7.68 \\
22 & 21.97 & Quercetin 3-methyl ether & 7.09 \\
23 & 22.65 & Pentadecanic acid,14-methyl- & 2.15 \\
24 & 22.9 & & 3.45 \\
& & &
\end{tabular}




\section{Experimental animals}

Twenty four (24) adult male Wister albino rats, weighing 150 to $200 \mathrm{~g}$, were used for the study. All animals were obtained from the animal house of Radiobiological Applications Department, Nuclear Research Center. Atomic Energy Authority, Egypt. They were fed on standard rat diet and water. The study was conducted in accordance with the guidelines set by CIOHS\& ICLAS International Guiding Principles for Biomedical Research involving animals(2012) which is in accordance with the Guide for the Care and Use of Laboratory Animals $\left(8^{\text {th }}\right.$ Edition, 2011,published by The National Academics Press, 2101 Constitution Ave, NW, Washington, DC20055, USA) This guide was approved by the Ethical committee at National Center for Radiation Research and Technology, Egyptian Atomic Authority, Cairo, Egypt(NCRRTEAEA).

\section{Experimental design}

The animals were randomly divided into four equal groups having (six rats each) Group, I served as a control and received orally a daily dose of $1 \mathrm{ml}$ normal saline for twelve successive days. Groups 2 and 4 were given olive leaves extract orally (150 mg/kg.b.wt.) According to Sarbishegi, Sarbishgi et al. (2017) in $1 \mathrm{ml}$ distilled water daily for twelve successive days.

On the $12^{\text {th }}$ day, $1 \mathrm{~g} / \mathrm{kg} . \mathrm{b}$. wt paracetamol suspension in $1 \mathrm{ml}$ saline was given orally to rats of groups 3 and 4 according to McGill et al. (2012). The rats were fasted overnight and were euthanized by cervical dislocation on the thirteenth day.

\section{Biochemical studies}

Blood was obtained from all animals. Serum was separated by centrifugation at $3000 \mathrm{rpm}$ at $30^{\circ} \mathrm{C}$ for $15 \mathrm{~min}$, collected into sterilized tubes and stored at $-20^{\circ} \mathrm{C}$. Serum biochemical parameters were analyzed. The serum aspartate aminotransferase (AST), alanine aminotransferase (ALT), total bilirubin, alkaline phosphatase (ALP), gammaglutamyltransferase $(\gamma-\mathrm{GT})$ and lactate dehydrogenase (LDH) were determined using Spinreact kits (S.A.U. Ctra. Santa Coloma, Spain). Alpha-Fetoprotein $(\alpha-\mathrm{FP})$ was determined using a rat radioimmunoassay kit (RIA), the Institute of Isotopes Co., Ltd. (IZOTOP). Hungary, according to Kroes et al., (1975). Total antioxidant capacity was determined using enzyme-linked immunosorbent assay kit (ELISA) (MyBioSource, San Diego, USA). Superoxide dismutase (SOD) was assayed according to the method of Kakkar et al. (1984).

\section{Preparation of liver homogenate}

After the rats were euthanized, the livers were rapidly removed. $500 \mathrm{mg}$ of each liver was weighed and homogenized with $5 \mathrm{ml}$ of $0.2 \mathrm{M}$ TrisEDTA (PH. 8.0). The homogenate was used for the estimation of glutathione reductase (GR) activity, by the procedure adopted by David and Richard (1983) and the level of malondialdehyde (MDA) was measured according to the method of Ohkawa, Ohishi and Yagi (1979).

\section{Histopathological examination}

Small pieces of liver tissues in each group were collected in $10 \%$ neutral buffered formalin for proper fixation. These tissues were processed and embedded in paraffin wax. Sections of 5-6 $\mu \mathrm{m}$ in thickness were cut and stained with hematoxylin and eosin. These sections were examined for histopathological changes and photographed (BANCROFT; STEVEN; TURNER, 1996).

\section{Statistical analysis}

The experimental data were analyzed by one-way ANOVA using Statistical Package for Social Sciences (SPSS) version 20. The mean difference was estimated using Duncan's multiple range test $(p<0.05)($ DUNCAN, 1955).

\section{RESULTS}

As shown in Table 2, total bilirubin, ALP, GGT, AST, ALT ,LDH and AFP significantly increased in paracetamol treated rats (group 3) by $41 \%, 34.8 \%, 63.3 \%, 55.5 \%, 80.4 \%, 140.4 \%$ and $224.3 \%$ respectively compared to the control group. The levels of those parameters decreased statistically in olive leaves extract plus paracetamol group (group4) by $25 \%, 42.3 \%, 32.4 \%, 15 \%, 16 \%$, $42.5 \%$ and $33,8 \%$ respectively compared to the paracetamol treated rats (group3).

The results reported in Table 3 show that rats treated with paracetamol (group 3) had a significant increase in urea, creatinine and MDA, levels by $37.8 \%, 25 \%$ and $31.5 \%$, respectively compared to the control. However the TAC, SOD and GR dropped by $43.3 \%, 38.8 \%$ and $51,28 \%$ respectively compared to the control. In rats administered olive leaves extract and paracetamol group (group 4), the values of urea, creatinine, MDA, were significantly decreased by $20.7 \%, 21 \%$ and $18.7 \%$ respectively with a significant increase in the levels of TAC, SOD and GR by $26.9 \%, 28.7$ ,89.41 respectively compared to the paracetamol treated rats (group3). 
Table 2. Effects of olive leaves extract on liver function tests in paracetamol-induced hepatotoxicity in male albino rats

\begin{tabular}{ccccc}
\hline $\begin{array}{c}\text { Groups } \\
\text { Parameters }\end{array}$ & C & OLE & PCM & PCM+OLE \\
\hline T.B(mg/dl) & $0.78 \pm 0.05$ & $0.69 \pm 0.10$ & $1.10 \pm 0.09^{\mathrm{ab}}$ & $0.82 \pm 0.04^{\mathrm{bc}}$ \\
\% of change & & -11.53 fromC & 4.02 fromC & -25.45 from PC $^{\mathrm{P}}$ \\
ALP(u/1) & $460.20 \pm 9.80$ & $393.90 \pm 8.00^{\mathrm{a}}$ & $620.60 \pm 11.60^{\mathrm{ab}}$ & $357.60 \pm 7.60^{\mathrm{c}}$ \\
\% of chance & -14.4 from C & 34.8 from C & -42.3 from PCM \\
GGT(u1) & $49.40 \pm 3.50$ & $49.50 \pm 2.80$ & $80.70 \pm 3.10^{\mathrm{ab}}$ & $54.50 \pm 1.40^{\mathrm{ac}}$ \\
\% of change & & 0.2 from C & 63.3 from C & -32.4 from PCM \\
AST(u) & $251.00 \pm 2.90$ & $229.60 \pm 1.70^{\mathrm{a}}$ & $390.50 \pm 19.40^{\mathrm{ab}}$ & $331.00 \pm 13.70^{\mathrm{abc}}$ \\
\% of change & & -8.5 fromC & 55.5 fromC & -15 from PCM \\
ALT(u) & $135.00 \pm 1.80$ & $106.30 \pm 2.60^{\mathrm{a}}$ & $243.50 \pm 14.20^{\mathrm{ab}}$ & $203.40 \pm 3.40^{\mathrm{abc}}$ \\
\% of change & & -21.2 from C & 80.4 fromC & -16.4 from PCM \\
LDH(ul) & $306.70 \pm 5.40$ & $267.20 \pm 28.00^{\mathrm{a}}$ & $737.40 \pm 19.20^{\mathrm{b}}$ & $423.80 \pm 37.10^{\mathrm{bc}}$ \\
\% of change & & -12.8 fromC & 140.4 fromC & -42.5 from PCM \\
AFP(ng/ml) & $0.41 \pm 0.01$ & $0.48 \pm 0.03$ & $1.33 \pm 0.10^{\mathrm{b}}$ & $0.88 \pm 0.10^{\mathrm{bc}}$ \\
\% 0f change & & 17 fromC & 224.3 fromC & -33.8 from PCM \\
\hline
\end{tabular}

The results are presented as means \pm SEM of 6 rats, P-values of less than 0.05 were considered significant; C (control), OLE (olive leaves extract), PCM (paracetamol), PCM+OLE (paracetamol+olive leaves extract)

$\%$ of change $\frac{\text { treatment-control }}{\text { control }} \times 100$

Table 3. Effect of olive leaves extract on kidney functions and oxidant and antioxidant status in paracetamolinduced hepatotoxicity in male albino rat

\begin{tabular}{ccccc}
\hline $\begin{array}{c}\text { Group } \\
\text { Parameters }\end{array}$ & $\mathbf{C}$ & OLE & PCM & PCM+OLE \\
\hline Urea(mg/dl) & $36.72 \pm 1.50$ & $32.61 \pm 0.80^{\mathrm{a}}$ & $50.62 \pm 1.40^{\mathrm{b}}$ & $40.11 \pm 1.80^{\mathrm{ac}}$ \\
\% of change & & -11.1 fromC & 37.8 fromC & -20.7 from PCM \\
Creatnine(mg/dl) & $1.04 \pm 0.10$ & $0.96 \pm 0.13$ & $1.30 \pm 0.10^{\mathrm{b}}$ & $1.02 \pm 0.10^{\mathrm{bc}}$ \\
\% of change & & -7.6 fromC & 25 fromC & -21 from PCM \\
MDA(Mmolg) & $133.42 \pm 5.00$ & $132.60 \pm 3.90$ & $175.47 \pm 2.50^{\mathrm{b}}$ & $142.60 \pm 6.40^{\mathrm{bc}}$ \\
\% of change & & -0.6 fromC & 31.5 fromC & -18.7 from PCM \\
TAC(ng/ml) & $6.87 \pm 0.30$ & $6.38 \pm 0.10$ & $3.89 \pm 0.10^{\mathrm{b}}$ & $4.94 \pm 0.12^{\mathrm{bc}}$ \\
\% of change & & -7.1 fromC & -43.3 fromC & 26.9 from PCM \\
SOD $(\mathrm{u})$ & $39.70 \pm 5.20$ & $41.49 \pm 1.30$ & $24.32 \pm 0.90^{\mathrm{b}}$ & $31.31 \pm 1.10^{\mathrm{bc}}$ \\
$\%$ of change & & 4.3 fromC & -38.8 fromC & 28.7 from PCM \\
GR(ng/g) & $3.49 \pm 0.04$ & $2.45 \pm 0.04^{\mathrm{a}}$ & $1.70 \pm 0.02^{\mathrm{b}}$ & $3.22 \pm 0.02^{\mathrm{ac}}$ \\
of change $\%$ & & $-29.7 \%$ from C & $-51.28 \%$ from C & $89.41 \%$ from PCM \\
\hline
\end{tabular}

The results are presented as means \pm SEM of 6 rats, P-values of less than 0.05 were considered significant; C (control), OLE (olive leaves extract), PCM (paracetamol), PCM+OLE (paracetamol + olive leaves extract)

$\%$ of change $\frac{\text { treatment-control }}{\text { control }} \times 100$ 
Possible protective...

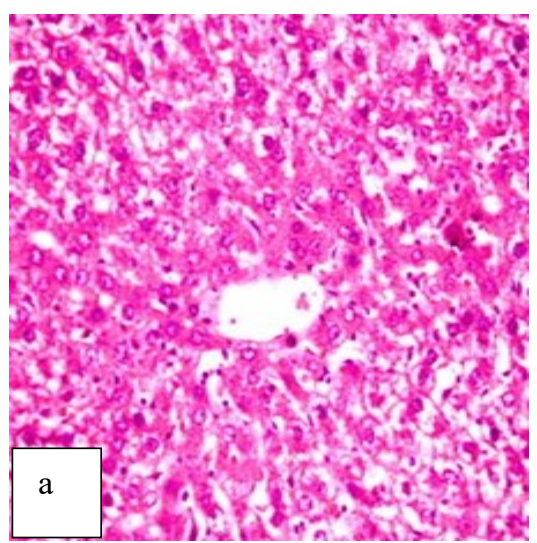

(1a): control group Liver showing apparently normal hepatocytes (H\&E X 400)

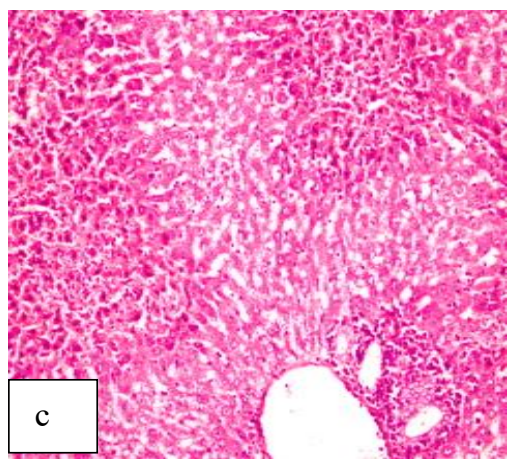

(1c): paracetamol group Liver showing multiple focal areas of necrotic hepatocytes infiltrated with mononuclear cells (H\&E X 400)

Figure 1. Liver histology

\section{DISCUSSION}

The present study was conducted to evaluate the hepatoprotective activity of olive leaves extract against overdose of paracetamol. The results demonstrated that paracetamol- treated rats showed impairment in liver functions, which is confirmed by the enhancement of the levels of hepatic marker enzymes. There were significant increases in the levels of liver markers (AST, ALT, ALP, GGT) and LDH activities. These elevations are the major diagnostic signs of liver dysfunction. Consistent with the obtained results, other studies showed a change in hepatic serum markers following administration of paracetamol (AJAYI; ADENIYI; BABAYEMI, 2009; SHABANA et al., 2012), where the elevations in serum are presumptive markers of drug induced alteration in the hepatocytes. Similarly, recent results showed an elevation in the activities of hepatic marker enzymes in rats following administration of paracetamol
TAHA, M. E. S.; KAMAL, A. M.; IBRAHIM, D. R.

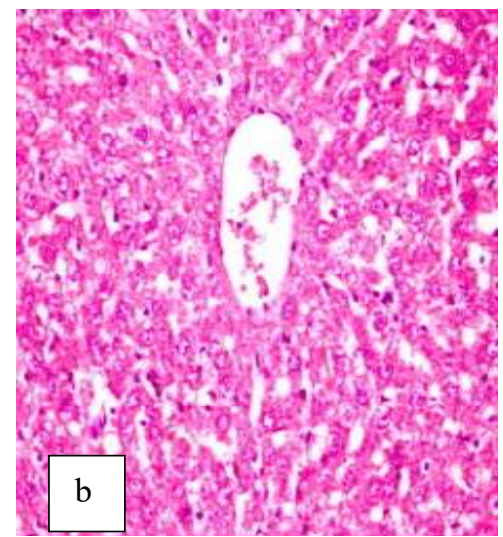

(1b): olives leaves extract group

Liver showing healthy hepatic cords and blood ((H\&E 400)

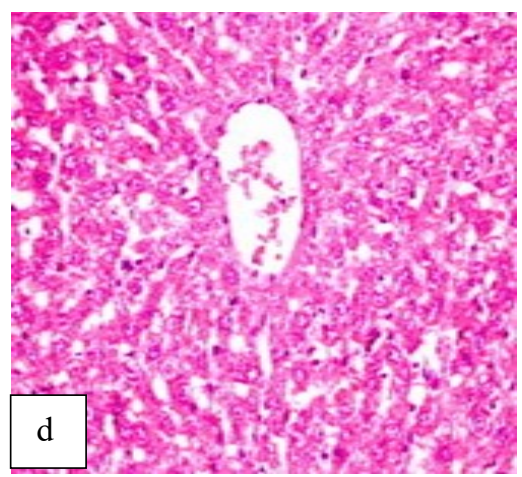

(1d): (paracetamol+ olive leaves extract group) Liver showing apparently normal hepatocyte (H\&E X 400)

(ADEBIYI; ABATAN, 2013; PARMAR et al., 2013, ALANTARY; REZK; SOLIMAN, 2014; KUMAR; RAMESH; MOHAN, 2014; OZOUGUIV; EYO, 2014; FOGHA et al., 2015; AJIBOYE, 2016; DWIVEDI et al 2016). Elevation in AST and ALT indicate a cellular damage and loss of functional integrity of the hepatocytes, and this elevation is attributed to leakage of plasma membrane of hepatocytes causing an increased serum hepatic enzymes. Gammaglutamyltransferase (GGT), and alkaline phosphatase (ALP) are membrane bound enzymes. The elevation of GGT activity is regarded as one of the most sensitive indices of hepatic damage. Administration of olive leaves shows apparently normal hepatocytes. This effect is in agreement with the accepted view that serum levels of transaminases return to normal with the healing of hepatic parenchyma and the regeneration of hepatocytes (AHMED; KHATER, 2001; EL FARAS; ELSAWAF, 2017). LDH catalyses the 
conversion of lactate to pyruvate using NAD + as coenzyme of NAD (BURTIS; ASHWOOD, 1986). The increase in LDH activity may be due to leakage of the enzyme from the tissues into the blood because of a cellular damage. The increase in ALP and bilirubin levels in paracetamol treated animals reflects the pathological alteration in biliary flow (ISLAM; ALAM, 2019). Hyperbilirubinemia was due to excessive heme destruction and block of bile duct within the liver, inhibition of the conjugation reaction and release of unconjugated bilirubin from damaged hepatocytes (HANAFY et al., 2016).

Treatment with olive leaves extract significantly improved the activities of hepatic markers. Consistent with the current data, previous studies revealed the hepatoprotictive activity of aqueous extract of olive leaves against paracetamol overdose-induced destruction of liver cells in male albino rats (KHALIL, 2004; AL ATTAR; ABU ZAID, 2013). A significant decrease in the activities of hepatic enzymes in OLE treated rats confirmed the protective effect of the extract having various phytoconstituents such as fatty acid (oleanolic and Pentaadecanoic acid, Octadecenoic acidCisVaccenic acid 11E, and Stearic acid) and Flavonoides e.g., Isovitexin, Astibin, Quercetin, BSitosterol, which exhibit hepatoprotective properties and have a role in preserving structural integrity of the hepatocellular membrane that could be responsible for the membrane stabilizing activity.

Nephrotoxicity results when there is insufficient glutathione in the renal parenchyma and occurs independently of hepatotoxicity depending on the balance of metabolism and the glutathione stores within the kidney (BOUTIS; SHANNON, 2001). In the present study, paracetamol administration caused a significant increase in serum urea and creatinine levels, leading to renal damage. Elevation in plasma concentration of these parameters is considered reliable for investigating drug-induced nephrotoxicity in animals (MANDAL et al., 2015). These results were in accordance with previous studies (ANTHONY; MBUH; EMMANUEL, 2012; SAXENA et al. 2012; SINI; NWODO; ALUMANAH, 2017) which reported that there was a significant increase in kidney markers (urea and creatnine) following administration of paracetamol overdose. Treatment with olive leaves extract resulted in decline of urea and creatnine in serum. This finding is in accordance with that of Zari and Al-Attar (2011) who reported that olive leaves extract ameliorated renal toxicity induced by carbendazim in rats. Additionally, Al-Sowayan and Mousa (2014) investigated the protective effect of olive leaves extract against $\mathrm{CCl} 4$ induced nephrotoxicity and reported that treatment with olive leaves extract significantly decline the elevation in urea and creatnine suggesting that the olive leaves extract protected CCl4-induced nephrotoxicity.

AFP is used as a diagnostic and predictive marker. In the present study, the results showed an increase in $\alpha$-feto protein in paracetamol treated group compared to the control. An increase in alpha-fetoprotein (AFP) following hepatic necrosis is considered indicative of hepatic regeneration. This result is in agreement with Schmidt and Dalhoff, (2005), who proved the occurrence of premalignant liver changes in intoxicated rats. Treatment with olive leaves extract significantly reduced serum AFP that may indicate the curative effect of OLE which was attributed to its polyphenol and flavonoids. This result is in accordance with Abdel-Hamid et al. (2011) who reported that administration of olive leaves extract significantly decreased the elevation in alpha feto protein (AFP) in hepatotoxicity rats induced by Trichloroacetic acid (TCA).The present finding was confirmed by histopathological alteration of liver in rats treated with paracetamol showing multiple focal area of necrotic hepatocytes infiltrated with mononuclear cells. The elevated level of MDA is in accordance with previous study of Farghaly and Hussein (2010), which showed the association between PCM toxicity and MDA. A significant elevation in hepatic MDA level weakling glutathione reductase (GR) activity, SOD and TAC was demonstrated in other studies (MANIMARAN; SARKAR; SANKAR, 2010; ALANTARY; REZK; SOLIMAN, 2014; WOJANAROVA et al., 2015; SAHEED, HENDTRIK; TOM, 2016; AJIBOYE, 2016; AMIN et al., 2017). These studies suggested enhanced lipid peroxidation leading to tissue damage and failure of antioxidant defense. Administration of OLE significantly ameliorated these changes suggesting that OLE extract containing phyto constituents such as oleuropein and hydroxytyrosol reverses the chronic inflammation and oxidative stress. This is in accordance with some studies (TRIPOLI et al., 2005; BULOTTA et al., 2013). It was reported that olive leaves extract had a high radical scavenging activity (WOJCIKOWSKI et al., 2007).

\section{CONCLUSION}

The finding of this study indicates that OLE possesses hepatoprotective properties against paracetamol overdose by inhibiting the physiological and histological alterations as well as decreasing oxidative stress. 
RESUMO: A sobredosagem de paracetamol (PCM) pode causar hepatotoxicidade com estresse oxidativo; o presente estudo foi realizado para estabelecer o possível efeito protetor do extrato de folhas de oliveira (OLE) na toxicidade induzida pelo paracetamol em ratos machos adultos. Vinte e quatro ratos machos adultos foram divididos em quatro grupos iguais: controle, grupo extrato de folhas de oliveira, grupo paracetamol e extrato de folhas de oliveira mais grupo paracetamol. Alguns parâmetros bioquímicos e histopatologia hepática foram avaliados. $\mathrm{O}$ tratamento com PCM aumentou significativamente aspartato aminotransferase sérica (AST), alanina aminotransferase (ALT), bilirrubina total, gama-glutamiltransferase (GGT), lactato desidrogenase (LDH), uréia, creatinina e alfa-fetoproteína. Verificou-se que o paracetamol aumenta significativamente o malonaldeído (MDA) e diminui a atividade da glutationa redutase (GR) no tecido e diminui significativamente a capacidade antioxidante total (TAC) e a superóxido dismutase (SOD) no soro. A administração de OLE causou uma diminuição significativa de AST, enzima ALT, bilirrubina total, GGT, LDH, creatinina, uréia, alfa-fetoproteína. Também foi observada melhora do status oxidante - antioxidante com extrato de folhas de oliveira, além de uma diminuição significativa no MDA e um aumento significativo no TAC no tecido hepático, com um aumento significativo na glutationa redutase (GR) e SOD no soro em comparação ao grupo tratado com paracetamol. As alterações patológicas químicas acompanharam a observação histopatológica, sugerindo resultado hepatoprotetor acentuado do extrato de folhas de oliveira. Pode-se concluir que o tratamento com extrato de folhas de oliveira (OLE) pode ser eficaz na diminuição da lesão hepática e do estresse oxidativo induzido pela overdose de paracetamol em ratos albinos machos

PALAVRAS-CHAVE: Paracetamol. Extrato de folhas de oliveira. Enzimas hepáticas. Estado oxidante-antioxidante.

\section{REFERENCES}

ABDEL-HAMID, N. M.; FAWZY, M. A.; El-MOSELHY, M. A. Evaluation of Hepatoprotective and Anticancer Properties of Aqueous Olive Leaf Extract in Chemically Induced Hepatocellular Carcinoma in Rats. American Journal of Medicine and Medical Sciences, V.1, n.1, p. 15-22, 2011. http// DOI: 10.5923/j.ajmms.20110101.03

ADEBIYI, E. O.; ABATAN, O. M. Protective Effects of Enantia chlorantha Stem Bark Extracts on Acetaminophen Induced Liver Damage in Rats. J.J.B.S, v. 6, n 4, p. 284-290, 2013. https://www.researchgate.net/publication/270879318 https://doi.org/10.12816/0001627

AHMED, M. B.; KHATER, M. R. Evaluation of the protective potential of Ambrosia maritime extract on acetaminophen induced liver damage. J Ethnopharmacol , v. 75, n. 2-3,p.169-174,2001 https://doi.org/10.1016/S0378-8741(00)00400-1

AJAYI, G. O.; ADENIYI, T. T.; BABAYEMI, D. O. Hepatoprotective and some haematological effects of Allium sativum and vitamin $C$ in lead exposed wistar rats. Inter .J .Medicine and Medical. Sci., v .1,n. 3, p .064-067,2009 .http://www.academicjournals.org/ijmms

AJIBOYE, O. T. Lophirones B and C Attenuate Acetaminophen-Induced Liver Damage in Mice: Studies on Hepatic, Oxidative Stress and Inflammatory Biomarkers. Journal of Biochemical and Molecular Toxicology, v.10, n.5, p.497-505, 2016. https://doi.org/10.1002/jbt.21814.

AL ATTAR, M. A.; ABU ZAID, M. I. Effect of Tea (Camellia sinensis) and Olive (Oleaeuropaea L.) Leaves Extracts on Male Mice Exposed to Diazinon. Bio Med Research International ,v. 2013, p.1-6, 2013. http://dx.doi.org/10.1155/2013/461415

ALANTARY, A. K.; REZK, M. Y.; SOLIMAN, K. E. A. Protective effect of ghrelin on paracetamol induced acute hepatotoxicity in rats. Journal of physiology and pathophysiology, v.5,n.2,p.7-14,2014. https://doi.org/10.5897/JPAP2014.0091 
AL-BASHER, G. I. Anti -fibrogentic and hepatoprotective potential of methanolic olive extract on cadmium induced toxicity in rats. Life Science Journal,v.15,n.7.p.1-11,2018. http://www.lifesciencesite.com. doi:10.7537/marslsj150718.01

AL-SOWAYAN, N. S.; MOUSA, H. M. Ameliorative effect of olive leaf extract on carbon tetrachlorideinduced nephrotoxicity in rats, Life. Science .Journal. v11.n5.p238-242,2014.

https://www.researchgate.net/publication/262297713

AMIN, K. A.; HASHEM, K. S.; ALSHEHRI, F. S.; AWAD, S. T.; HASSAN, M. S. Antioxidant and Hepatoprotective Efficiency of Selenium Nanoparticles Against Acetaminophen-Induced Hepatic Damage. Biol. Trace .Elem. Res, v. 175, n.1, p. 136-145,2017.https://www.ncbi.nlm.nih.gov/pubmed/27220627 https://doi.org/10.1007/s12011-016-0748-6

ANTHONY, O. E; MBUH ,A. F.; EMMANUEL, M. P. Phytochemical screening, and assessment of ameliorating effect of aqueous and ethanolic extracts of Gmelina arborea on drug induced hepatic and renal insufficiency in rats. Pak J Pharm Sci, v. 25, n. 2, p. 457-

461,2012.https://www.ncbi.nlm.nih.gov/pubmed/22459477

BANCROFT, D.; STEVEN, A.; TURNER, R.. Theory and practice histological techniques. 4thed Churchil livingstone, Edinburgh, London, Melbourrnepp. v .183, n. 2,p. 127-248,1996. https://onlinelibrary.wiley.com

BULOTTA, S.; OLIVERIO, M.; RUSSO, D.; PROCOPIO, A. Biological activity of oleuropein and its derivatives. In: Ramawat K. G., Mérillon J. M., editors. Natural Products. Heidelberg, Germany: Springer, p. 3605-3638, 2013 .https://www.ncbi.nlm.nih.gov/pmc/articles/PMC4700197/ https://doi.org/10.1007/978-3642-22144-6_156

BOUTIS, K.; SHANNON, M. Nephrotoxicity After acute severe acetaminophen poisoning in adolescents. J. Toxicol. Clin.Toxicol, v .39, n.5, p.441-5, 2001 .https://www.ncbi.nlm.nih.gov/pubmed/11545233 https://doi.org/10.1081/CLT-100105413

BURTIS, L. A.; ASHWOOD, E. R. Textbook for Clinical Chemistry. W.B. Saunders Company, Philadelphia, Pennsylvania, 1986.

CHINNAPPAN, S. M.; GEORGE, A.; THAGGIKUPPE, P.; CHOUDHARY, Y.; CHOUDHARY, V. K.; RAMANI, Y.; DEWANGAN ,R. Nephroprotective Effect of Herbal Extract Eurycoma longifolia on Paracetamol-Induced Nephrotoxicity in Rats, Evidence-Based Complementary and Alternative Medicine V. 2019, 2019, Article ID 4916519, 6 pages https://doi.org/10.1155/2019/4916519

DAS, J.; GHOSH, J.; MANNA, P.; SIL, P. C. A. Acetaminophen induced acute liver failure via oxidative stress and JNK activation: protective role of taurine by the suppression of cytochrome P450 2E1. Free. Radical. Research ,V .44, n. 3, p. 340-55,2010. https://doi.org/10.3109/10715760903513017

DAVID, H.; RICHARD, J. S; In: Bergmeyer J, Grab M. editiors. Methods of enzymatic analysis. rd ed., VerlagChemie; Weinhein Deer Field Beach, P. 358, 1983.

DUNCAN, D.B. Multiple F test. Biometrics,p. 1-142, 1955.

DWIVEDI, K. V.; MISHRA, J; SHRIVASTAVA, A. Efficacy study of Livartho against paracetamol induced Hepatotoxicity in adult Sprague Dawley Rats. Drug Metabolism and Toxicology, v.5,n.6,p .1-7,2016. https://doi.org/10.4172/2157-7609.1000175

EL FARAS, A. A; ELSAWAF, A. L. Hepatoprotective activity of quercetin against paracetamol-induced liver toxicity in rats. Tanta Med J , v.45, n.2, p.92-8,2017. http://www.tdj.eg.net/text.asp?2017/45/2/92/216690 https://doi.org/10.4103/tmj.tmj_43_16 
FARGHALY,H. S; HUSSEIN, M. A. Protective effect of curcumin against paracetamol-induced liver damage. Australian Journal of Basic and Applied Sciences V. 4, n .9, p. 4266-4274,2010.

https://www.researchgate.net/publication/279718136

FOGHA, J. V.; TCHAMGOUE, D. A.; DOMEKOUO, L. U.; TAKANG, P. A.; AGBOR,G. A. Morinda Lucida Stem Bark Protects Paracetamol induced liver damage. Int. J. Pharm. Sci. Rev. Res, v.31,n.1 p.198-204,2015. https://www.researchgate.net/publication/273502248

HAKEMI, S. G.; SHARIFIFAR, F,; HAGHPANAH, T.; BABAEE, A .; EFTEKHAR-VAGHEFI, S.H. The Effects of Olive Leaf Extract on The Testis, Sperm Quality and Testicular Germ Cell Apoptosis in Male Rats Exposed to Busulfan. Int J Fertil Steril, v. 13, n.1 , p. 57-65, 2019.

https://www.ncbi.nlm.nih.gov/pmc/articles/PMC6334023

HANAFY, A.; ALDAWSARI, M. H.; BADER, M. J.; IBRAHIM, A. K.; ABDELHADY, S. E. Evaluation of Hepatoprotective Activity of Adansoniadigitata Extract on Acetaminophen-Induced Hepatotoxicity in Rats.

Evidence-Based Complementary and Alternative Medicine, v. 2016,P. 1-7 2016.

http://dx.doi.org/10.1155/2016/4579149

ISLAM, R.; ALAM, M. J .Evaluation of liver protective activity of Moringa oleifera bar'extract in paracetamol induced hepatotoxicity in rats. bioRxiv, Jan,p.513002, 2019.http://dx.doi.org/10.1101/513002

KAKKAR, P.; DAS, B.; VISWANATHAN, P. N. A modified spectrophotometric assay of superoxide dismutase. Indian .J .Biochem. Biophys, v.21,p. 130-162, 1984.

https://pdfs.semanticscholar.org/ed30/b1024e83d2b22089f0419ca5fb73a3e0faa5.pdf

KHALIL, E. A. M. Evaluation of the hepatoprotective activity of an aqueous extract of olive leaves in male albino rats. Egypt. J.Hosp.Med, v. 15,p.118-123, 2004. DOI: 10.12816/EJHM.2004.18191

KIM ,M. S. J.; LEE, M. Y; KWON, D. Y; KIM, S. Y; KIM. Y. C. Alteration in metabolism and toxicity of acetaminophen upon repeated administration in rats, J .Pharmacol. Sci ,v.111,n.2,p. 175-81,2009.

https://www.ncbi.nlm.nih.gov/pubmed/19834287 https://doi.org/10.1254/jphs.09151FP

KROES, R. S.; SONTAG, J. M.; SELL, S.; WILLIAMS, G. M; JOHN, H.; WEISBURGER, J. H. Elevated Concentration of Serum a Fetoprotein in Rats with Chemically Induced Liver Tumors. Cancer Research, v.35, p.1214-1217, 1975. https://www.ncbi.nlm.nih.gov/pubmed/47266

KUMAR, C. H.; RAMESH, A; MOHAN, G. K .Hepatoprotective Effect Of Ethanolic Extract Of Ficus Mollis On Paracetamol Induced Liver Damage In Albino Rats. International Research Journal Of Pharmacy, v.5, n. 6, p.485-488,2014. https://www.researchgate.net/publication/271236428 https://doi.org/10.7897/22308407.0506100

MANDAL, A.; PATRA, A.; MANDAL, S.; ROY, S.; MAHAPATRA, S. D.; MAHAPATRA, T. D.; PAUL, T.; DAS, K.; MONDAL, K. C.; NANDI, D. K. Therapeutic potential of different commercially available synbiotic on acetaminophen-induced uremic rats. Clin. Exp.Nephrol., v.19 , n.2, p. 168-177,2015. https://link.springer.com/article/10.1007/s10157-014-0971-4

MANIMARAN, A.; SARKAR, S. N.; SANKAR, P. Influence of repeated preexposure to arsenic on acetaminophen-induced oxidative stress in liver of male rats, Food and Chem. Toxicol , v. 48, n.2, p.605-610, 2010. https://www.ncbi.nlm.nih.gov/pubmed/19932728 https://doi.org/10.1016/j.fct.2009.11.039

MCGILL, M. R.; WILLIAMS, C. D.; XIE ,Y.; RAMACHANDRAN ,A.; JAESCHKE, H. Acetaminopheninduced liver injury in rats and mice: comparison of protein adducts, mitochondrial dysfunction, and oxidative stress in the mechanism of toxicity. Toxicol. Appl .Pharmacol, v.1 n. 264(3) p. 387-94, 2012 doi: 10.1016/j.taap.2012.08.015. Epub 2012 Aug 23 PMID: 22980195 https://doi.org/10.1016/j.taap.2012.08.015 
MOHAMED-SALEEM, T.; CHETTY, S.; M.; RANKANTH, S.; RAJAN, V.; S.; T.; KUMAR, K.; M.; GANTHAMAN, K . Hepatoprotective Herbs a review. Inter. J. Res .Pharmaceutical. Sci, v. 1, n. 1, p.1-5, 2010. https://www.pharmascope.org

OHKAWA, H.; OHISHI, N,; YAGI, K.Assay for lipid peroxides in animal tissues by thiobarbituric acid reaction, Anal. Biochem , v. 95 , n. 2, p.351-358, 1979. https://www.ncbi.nlm.nih.gov/pubmed/36810 https://doi.org/10.1016/0003-2697(79)90738-3

OZOUGWU, J. C. and EYO, J. E. Heptoprotective effects of Allium Cepa (onion) extracts against paracetamol induced liver damage in rats. African. Journal of Biotechnology, v. 13 n. 26, p.2679-2688, 2014. https://doi.org/10.5897/AJB2014.13815

PARMAR, M. Y.; SHAH, P. A; VAISHALI, T.; THAKKAR, V. T; AL-REJAIE, S; ABDULLAH, H.; ALASSAF, A. H.; GANDHI, T. R. Hepatoprotective and antioxidant activity of methanolic extract of vetiveria zizanioides roots against paracetamol-induced liver damage in rats Life Science Journal , v.10, n. 4, p.11841190, 2013. https://www.researchgate.net/publication/258240460

RUSSMANN, S.; KULLAK-UBLICK, G.A.; GRATTAGLINO, I. Current concepts of mechanism in drug induced hepatotoxicity, Curr. Med. Chem, v. 16,n. 23,p. 3041-3053,2009.

https://www.ncbi.nlm.nih.gov/pubmed/19689281 https://doi.org/10.2174/092986709788803097

SAHEED, S.; HENDTRIK, F. O.; TOM, A. A. Zea mays, Stigma maydis prevents and extenuates acetaminophen-perturbed oxidative onslaughts in rat hepatocytes, Pharmaceutical. Biology, v. 9, n. 5, p.26642673, 2016. https://www.ncbi.nlm.nih.gov/pubmed/27159805 https://doi.org/10.1080/13880209.2016.1178307

ŞAHIN, S.; ŞAMLI, R. Optimization of olive leaf extract obtained by ultrasound-assisted extraction with response surface methodology, Ultrason. Sonochem, v. 20, n. 1, p.595-602,2013.

https://www.ncbi.nlm.nih.gov/pubmed/22964032 https://doi.org/10.1016/j.ultsonch.2012.07.029

SARBISHGI, M.; GORGICH, E. A. C.; KHAJAVI, O . Olive Leaves Extract Improved Sperm Quality and Antioxidant Status in the Testis of Rat Exposed to Rotenone. Nephro .urol .Mon, v. 9, n. 3, p. e47127, 2017.https://www.researchgate.net/publication/316490653 https://doi.org/10.5812/numonthly.47127

SAXENA, M.; SHAKYA, A.;K.; SHARMA, N.; SHRIVASTAVA, S.; SHUKLA, S. Therapeutic efficacy of Rosa damascena Mill. On acetaminophen-induced oxidative stress in albino rats. J Environ Pathol Toxicol Oncol, v.31, n.3 ,p.193-201,2012 https://www.ncbi.nlm.nih.gov/pubmed/23339694 https://doi.org/10.1615/JEnvironPatholToxicolOncol.v31.i3.10

SCHMIDT, L.; E.; DALHOFF, K. Alpha-fetoprotein is a predictor of outcome in acetaminophen-induced liver injury, Hepatology, v. 41, n . 1, pp. 26-31, 2005. https://www.ncbi.nlm.nih.gov/pubmed/15690478 https://doi.org/10.1002/hep.20511

SEHRAWAT, A.; KHAN, T. H.; PRASAD, L.; SULTANA, S. Buteamonosperma and chemomodulation : protective role against thioacetamide mediated hepatic alterations in Wister rats, Phytomed, v.13, n. 3,p. 157 163, 2006. https://www.ncbi.nlm.nih.gov/pubmed/16428022 https://doi.org/10.1016/j.phymed.2004.11.007

SHABANA, M.; B.; IBRAHIM, H.; M.; SOHEIR, E. M.; MARWA, G. E. Influence of rifampicin and tetracycline administration on some biochemical and histological parameters in albino rats. The journal of Basic \& Applied Zoology, v. 65, n.5, p. 299-308, 2012.https://www.researchgate.net/publication/257737069 https://doi.org/10.1016/j.jobaz.2012.10.009

SINI, J.; M.; NWODO, O.; F.; C. ALUMANAH, E.;O. Hepatoprotective activity of aqueous extract of Combretum sericeum roots against paracetamol induced hepatic damage in rats, Journal of Scientific Research and Studies, v.4, n. 2, p. 40-46, 2017. http://www.modernrespub.org/jsrs/index.htm 
SUBRAMONIAM, A.; EVANS, D. A.; RAJASKAHRAN, S. P.; PUSHPANGADAN, P. Hepatoprotective activity of Trichopus Zeylanicus extracts against paracetamol induced damage in rats, Ind. J .Expect. Biol, v. 36, n.4, p.385-389, 1988 . https://www.ncbi.nlm.nih.gov/pubmed/9717449

TRIPOLI, E.; GIAMMANCO, M.; TABACCHI, G.; MAJO, D.; GIAMMANCO, S.; GUARDIA, M. The phenolic compounds of olive oil: structure, biological activity and beneficial effects on human health, Nutr. Res. Rev, v. 18, n. 1, p.98-112, 2005. https://www.ncbi.nlm.nih.gov/pubmed/19079898 https://doi.org/10.1079/NRR200495

WANG, L.; GENG, C.; JIANG, L.; GONG, D.; LIU ,D.; YOSHIMURA, H.; ZHONG, L. The antiatherosclerotic effect of leaves extract is related to suppressed inflammatory response in rabbits with experimental atherosclerosis, Eur. J .Nutr, v.47, n. 5, p.235-43, 2008.

https://www.ncbi.nlm.nih.gov/pubmed/18654736 https://doi.org/10.1007/s00394-008-0717-8

WOJANAROVU, L.; KUTINOVA CANOVA, N.; FARGHALI, H.; KUCERA, T. Sirtuin 1 Modulation in Rat Model of Acetaminophen-Induced hepatotoxicity Physiol Res, v.64, n. 4, p. S477-87,2015.

https://www.ncbi.nlm.nih.gov/pubmed/26681077

WOJCIKOWSKI, K. L. STEVENSON, D. LEACH, H. WOHLMUTH; G. GOBE,: Antioxidant capacity of 55 medicinal herbs traditionally used to treat the urinary system: a comparison using a sequential three-solvent extraction process. The Journal of Alternative and Complementary Medicine, v.13, n.1, p.103-110, 2007 .https://doi.org/10.1089/acm.2006.6122

ZARI, T.A; AL-ATTAR, A. ; M. Therapeutic effects of olive leaves extract on rats treated with a sublethal concentration of Carbendazim, Eur. Rev. Med. Pharmacol. Sci, v.15, n. 4, 413-426, 2011.

https://www.ncbi.nlm.nih.gov/pubmed/21608437 